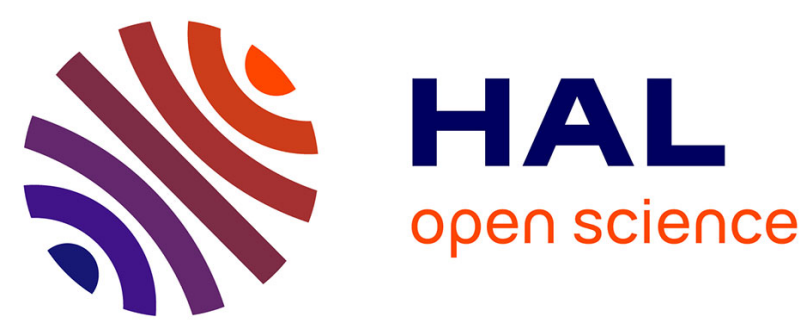

\title{
Assessing ICT Access Disparities Between the Institutional and Home Front: A Case of University Students in South Africa's Eastern Cape
} Sam Takavarasha, Liezel Cilliers, Willie Chinyamurindi

\section{- To cite this version:}

Sam Takavarasha, Liezel Cilliers, Willie Chinyamurindi. Assessing ICT Access Disparities Between the Institutional and Home Front: A Case of University Students in South Africa's Eastern Cape. 13th IFIP International Conference on Human Choice and Computers (HCC13), Sep 2018, Poznan, Poland. pp.45-59, 10.1007/978-3-319-99605-9_4 . hal-02001929

\section{HAL Id: hal-02001929 \\ https://hal.inria.fr/hal-02001929}

Submitted on 31 Jan 2019

HAL is a multi-disciplinary open access archive for the deposit and dissemination of scientific research documents, whether they are published or not. The documents may come from teaching and research institutions in France or abroad, or from public or private research centers.
L'archive ouverte pluridisciplinaire HAL, est destinée au dépôt et à la diffusion de documents scientifiques de niveau recherche, publiés ou non, émanant des établissements d'enseignement et de recherche français ou étrangers, des laboratoires publics ou privés.

\section{(c)(1)}

Distributed under a Creative Commons Attribution| 4.0 International License 


\title{
Assessing ICT access disparities between the institutional and home front:
}

\author{
A case of university students in South Africa's Eastern Cape
}

\author{
Sam Takavarasha Jr ${ }^{[0000-0002-0845-0677]}$ Stakavarasha@ufh. ac . za; \\ Liezel Cilliers ${ }^{[0000-0001-9493-4311]}$ Lcillierseufh.ac. za; \\ Willie Chinyamurindi ${ }^{[0000-0002-4139-4224]}$ WChinyamurindi@ufh.ac . za
}

University of Fort Hare, South Africa.

\begin{abstract}
Information and Communication Technologies (ICTs) have been used to promote equality and inclusivity, foster human development, enhance opportunity and fight poverty in developing countries. In spite of this effort, inequality to ICT access persists in developing countries like post-apartheid South Africa. This paper contributes to the ICT4D discourse by investigating ICT access disparities between various actors within a country. The theoretical foundation adopts elements of Engeström's [1] activity theory as a conceptual lens for examining the access disparities experienced by users at home and within a formal institutional activity system, such as a university. Fifteen in-depth interviews were conducted with university students at two campuses of a previously disadvantaged university in the Eastern Cape province of South Africa. The study shows that the reason for different access, limited access on the home front and unlimited access on the institutional front, was due to access cost, lack of devices, inadequate skills and lack of awareness of the value of internet access. We conclude that these factors worsen poverty by limiting access to opportunities for the majority of the population that lacks institutional access.
\end{abstract}

Keywords: Key Words: ICT access disparities; Activity theory; South Africa; social exclusion

\section{Introduction}

Several Information Systems scholars have presented Information and Communication Technologies (ICTs) as effective tools to improve inequality $[2,3,4]$. ICTs can be used to fight poverty, foster development and reducing inequalities to economic access in the information age [5]. While acknowledging the usefulness of other social, economic and technical imperatives, the importance of sustainable and affordable ICT access has been urged in literature as a critical driver of inclusivity in the information age [6].

Some key applications of ICT include agriculture, remittance economy, education and healthcare $[7,8]$. The usefulness of ICTs in supporting these essential sectors of the economy has compelled information systems scholars to promote universal access. The strategic nature of ICT enabled applications suggests that unequal access to ICTs 
will inevitably worsen social exclusion as well as economic inequalities between communities in the proximate future. Social exclusion refers to the whole or partial exclusion of individuals and population segments from the opportunities available to the society they live in [9]. To mitigate against social exclusion, several measures have been employed to ensure sustainable and affordable access by disadvantaged communities. These measures include the use of free basics [10] community networks [6]; telecentres [11] and infrastructure sharing [12].

Studies on the digital divide have often focused on the availability and unavailability of Internet access between and within countries [13]. This is in spite of the growing number of IS scholars that call for a shift beyond the elementary idea of binary access or lack thereof $[14,15]$. Socio-technical scholars of IS advocate for an understanding of both the technical and the social imperatives that affect the usage of ICTs. They view the usage of IS and ICTs as dependent on social phenomena that influence the users' ability to access and effectively use ICTs as articulated by Bednar and Welch [16]. This is supported by the United Nations [17] that also posits that the realization of ICT capabilities depends on the interface between technological and human factors.

Against this background, this study endeavours to analyze the inclusivity of ICT access within a country by comparing the home and institutional platforms. The home platform, hereafter operationalized as the home activity system, is used as a proxy for ordinary citizens' access. Likewise, the university activity system represents the ideal quality of access that institutions achieve with the same ICT penetration. These two activity systems were chosen to expose the difference in access to use ICT as a tool for development and opportunity enhancing access to information. In developing countries, like South Africa, where enclaves of affluence exist alongside expanses of extreme poverty, the reasons why one segment of the population fail to exploit the available opportunities that ICT provides are often not well understood. South Africa was chosen for the historical and political profile that are believed to have shaped people's social relations into structural exclusion that affects these previously marginalized groups [18].

Third generation activity theory (also called, cultural-historical activity theory) was adopted as a theoretical lens for this study. The theory can conceptualize the interaction between a subject and an object using a tool for achieving a particular outcome. Activity theory conceptualizes this interaction in a way that considers social, cultural and historical contexts of the unit of analysis. Unlike the earlier generations that only analyze the subject-tool-object interaction, the third generation also enables such an investigation in the contexts of two activity systems as discussed in section 2. It enables contextualism by investigating the Rules, Community and Division of labour that shape the use of Tools (i.e. ICTs) by Human subjects (students) in their endeavour to pursue ICT enabled opportunities.

The study uses 15 in-depth interviews conducted at a previously disadvantaged university in South Africa's Eastern Cape province. University students were chosen as the research population because of their access to the internet in both the home and institutional activity systems. The objective of this study is achieved by answering the following research question: What are the factors that influence the disparities in ICT access between the home and the institutional front if any? 


\section{$2 \quad$ Literature review}

The challenge of inclusive ICT access has been situated at the centre of The Information and Communication for Development (ICT4D) policymaking debate. This is because of the importance of ICT capabilities such as more efficient in economic and social processes, improving the effectiveness of cooperation between various stakeholders, and increasing the amount of information available to people, businesses and governments [17]. UNESCO [19] also draws parallels between digital inclusion and poverty reduction. They propose that ICT can provide a voice to marginalized communities through interventions in a context-specific manner that respects local socio-political and socio-economic processes, meaning making, autonomy and expression.

Zavaleta et al., [20] posit that social isolation or deprivation of social connectedness is a core impediment to the achievement of well-being. Social exclusion studies have also focused on the potential of ICTs to foster inclusive services to disadvantaged groups. This includes inclusive health care access [21,22] and inclusive education by disadvantaged groups like the disabled [23], among other subjects. The body of literature on inclusive education provides insights that advocates of ICT access can use. The merits of inclusivity access as an approach to developing digital skills and access to opportunities to previously disadvantaged communities in developing countries cannot be overestimated. For instance, many communities that are still affected by social exclusion challenges several years after the democratic dispensation in South Africa cannot escape their plight without inclusive interventions. They suffer under-investment in rural areas, inadequate access to markets and unfair market conditions, inadequate access to advanced technologies, weak infrastructure, high production and transport costs, gender asymmetry in access to assets and services, conflicts, HIV/AIDS, natural disasters, deforestation, environmental degradation and loss of biodiversity, and dependency on foreign aid [7]. This challenges both a result and a cause of previous and ongoing poverty traps as articulated by Sachs [24].

Literature shows that marginalized groups lag behind in the adoption and acceptance of new technologies. We argue that this applies to marginalized groups on the home activity system in comparison with the unlimited access on the institutional front. For instance, Roupa et al. [25] found that elderly citizens make less extensive use of services and opportunities offered by mobile phone technologies. They were mainly using mobile phones for making phone calls yet the few of them that used advanced technologies reported high satisfaction with the way that these technologies improved their lives. This shows that access to technologies is not synonymous with effective usage that supports the benefits of ICT enabled opportunities.

There has been some effort to promote universal access to ICTs [26]. Some of these efforts have focused on technologically oriented solutions while others have been socially embedded $[27,28]$. The technological approach has been criticized for assuming that availing technologies to under privileged people would result in the adoption of ICT to improve livelihoods $[29,30]$. On the other hands, the social embeddedness approach sought to align technologies to the social imperatives that determine livelihood choices in a community. Given the underutilization of interventions that employed adequate technologies like telecentres [31], this study suggests that an appreciation of the 
socio-economic and socio-political context is necessary for understanding the ICT adoption by a community.

Consequently, this study is situated on at the intersection of activity theory's application in ICT4D [32, 33], education [34, 35], and IS research [36]. Vygotsky's [37] Activity Theory (AT) is an analytical technique for identifying tensions and contradictions that exist among issues and problems that can arise in an activity. There are three generations of AT namely the first, second and third generations. The first generation AT simply consists of a subject and object that are mediated by tools [34]. The second generation AT situates the interaction of a subject and object in a contextual setting of a community that is governed by rules and division of labour which affect the undertaking of the activity [1].

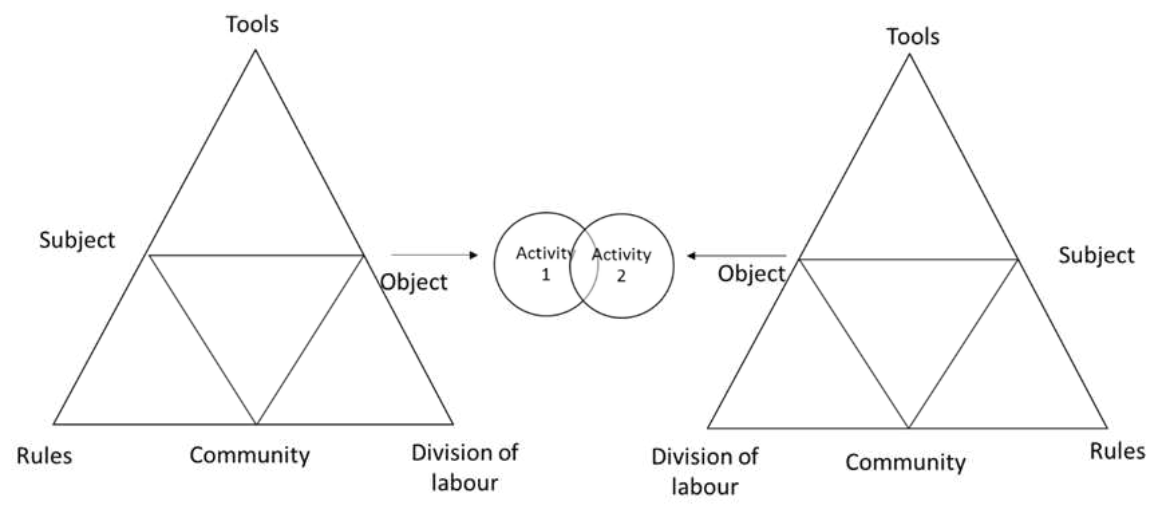

Fig. 1. Third generation activity theory [34]

Finally, the third generation AT expands on the seconds by including connected activities (Figure 1). The dual-activity system depicts the outcome of the interaction of two activities when activities come into contact with each other to produce an outcome [1]. This study, therefore, adopts the third generation AT to compare the difference between two digital exposure activity systems. These are the school system and the home system. The university student is the subject, and the usage of ICTs is the object. See figure 2 for a representation of the application of AT in this study.

The Research Context: This study was conducted at an institution of higher learning in the Eastern Cape of South Africa. South Africa is a sub-Saharan African country. South Africa has a Gini-coefficient of 0.66 to 0.7 which makes it one of the countries with the most inequality in the world [38]. The institution under study is a previously disadvantaged university, and most of the students are from impoverished rural areas in the Eastern Cape. The Eastern Cape has been reported to have the second lowest Internet access at $37 \%$ in South Africa. At least $11.3 \%$ of the population access the Internet through educational institutions and Internet cafes, while in 2014 the majority of the population (80\%) accessed the Internet through mobile devices [39]. While the institution has three campuses, this study was conducted at the two biggest campuses. Most of the students 
that are enrolled at these two campuses are below the age of 23 , unlike the third campus where the student profile tends to lean towards more mature, working adults which was not the population chosen for this study.

\section{Methods and approach}

This study adopts an interpretive paradigm for conducting case studies as articulated by Klein and Myers [40]. Of the seven principles for interpretive case studies, principle of Dialogical Reasoning which requires 'sensitivity to possible contradictions between the theoretical preconceptions guiding the research design and actual findings.' We also adopted the principles of Contextualization which calls for "critical reflection of the social and historical background of the research setting. ' ${ }^{1}$. While activity theory is often considered to be a paradigm, we adopted these principles of interpretivism because they complement activity theory's quest for both contradictions and contextualization.

In-depth interviews were conducted with students from two campuses of a university in South Africa's Eastern Cape Province. The combined student population from these two campuses are approximately 15000 . The study participants were selected making use of a convenient sampling allowing for gender and year of study. The interview process reached the saturation point after 15 interviews were conducted.

The interview guide was designed after a literature review was conducted to ascertain the reasons why ICT access are limited in developing countries. This allowed the researchers to have a deeper understanding of the reasons behind the differences in Internet access between the two activity systems. The researchers also attempted to conduct both exploratory and confirmatory research on the themes identified from literature as well as the theoretical framework.

A pilot study was conducted with three students that were not part of the study to validate the interview guide's user-friendliness. A few problems were identified through the user feedback, and these were documented and used to refine the final version of the guide. The ethical approval to conduct the study was obtained from the University's Research and Ethics Committee.

The qualitative evidence was analyzed using selective coding [41] from the grounded theory methodology for analysis as articulated by Matavire \& Brown [42]. After the first two interviews, preliminary coding of the data was conducted. The coding process was repeated after each interview to assess the emergence of new codes.

\section{$4 \quad$ Research Findings}

This section presents a summary of the results of the in-depth interviews. Selected quotes from the in-depth interviews are categorized by the components of Engeström's [43] third-generation activity theory.

\footnotetext{
${ }^{1}[40]$ p. 72
} 
Table 1. Interview results of the experience of subjects at University and home

\begin{tabular}{|c|c|c|}
\hline & UNIVERSITY & HOME (rural \& city) \\
\hline$\underset{⿱ 乛}{\vec{U}}$ & $\begin{array}{l}\text { - I am from a very small town called } \\
\text { Flagstaff, I grew up in rural areas, } \\
\text { and I came here when I was } 19 y \text { years, } \\
\text { and there was a course for computer } \\
\text { in my first year, and that was the first } \\
\text { time I learned to use a computer. Ai1 } \\
\text { - "I was } 19 \text { years in } 2012 \text {, and I learned } \\
\text { for the first time in university. There } \\
\text { was an orientation day, and we were } \\
\text { supposed to write a test during regis- } \\
\text { tration first year, I wrote the test and } \\
\text { failed, but then it was just a test to } \\
\text { check if I can use the internet and } \\
\text { computer, and then I leaned by my- } \\
\text { self." Ti4 } \\
\text { - "I haven't been formally trained, but } \\
\text { just from my general knowledge I } \\
\text { can identify valuable information } \\
\text { just by looking at the source of the } \\
\text { information and the content of the } \\
\text { information," Si8 } \\
\text { - "No I have never been taught on how } \\
\text { to buy online or how to treat others, } \\
\text { I have bought something online, and } \\
\text { I wouldn't really say I have been } \\
\text { taught. On how to protect myself or } \\
\text { my own privacy because I think for } \\
\text { me it comes with what you want to } \\
\text { be exposed to on the internet and I } \\
\text { just limit the information I put on the } \\
\text { internet especially about myself, so I } \\
\text { would say for me it has always been } \\
\text { a self-taught skill." Si5 }\end{array}$ & $\begin{array}{l}\text { - "... No, I got my first smartphone this } \\
\text { year and at home, I had my first phone } \\
\text { when I was doing grade-10 called V360 } \\
\text { for calls and text-messages." Ail } \\
\text { - "There is a huge gap and need for train- } \\
\text { ing. If I can give you an example of my } \\
\text { Dj career, some other things that DJs } \\
\text { write are too offensive...because those } \\
\text { guys are illiterate' They just know how } \\
\text { to play music and they can't really deal } \\
\text { with criticisms from social media and } \\
\text { other people. It's like you are running a } \\
\text { business and so some people will al- } \\
\text { ways complain that they don't like this } \\
\text { and that. ..and these guys would take it } \\
\text { negatively but me I would always take } \\
\text { it differently because I have got those } \\
\text { skills." Mi3 } \\
\text { - I have never used internet to buy any- } \\
\text { thing, you know when you not used to } \\
\text { these digital things and you hear people } \\
\text { saying there are scams in buying things } \\
\text { online, and then you become scared } \\
\text { even when you want to buy, } \\
\text { - Yes, she did teach me and even at } \\
\text { school, we were taught that we must } \\
\text { not just use the internet anyhow be- } \\
\text { cause one day you going to get a job } \\
\text { and they will check your character on } \\
\text { the internet and even Facebook. Then it } \\
\text { will be difficult for you if they find } \\
\text { something negative to be hired for cer- } \\
\text { tain job position or even at all because } \\
\text { of what you once posted on the internet. }\end{array}$ \\
\hline & $\begin{array}{l}\text { - Learned internet at university } \\
\text { - No e-commerce exposure } \\
\text { - No information literacy train- } \\
\text { ing }\end{array}$ & $\begin{array}{l}\text { - Late smart phone adopter } \\
\text { - No digital etiquette training } \\
\text { - No e-commerce exposure } \\
\text { - Warned to be modest on social } \\
\text { media }\end{array}$ \\
\hline
\end{tabular}

The university student are the subject of the home and university activity systems. The study shows that the millennials learn their digital skills at university. They however lack information literacy training and e-commerce exposure. At the home front they are late adopters who lack digital etiquette training and e-commerce exposure although they are warned to exercise modesty with social media. 
Table 2. The rules that control the conduct of subjects the home and university activity system

\begin{tabular}{|c|c|c|}
\hline & UNIVERSITY & HOME (rural \& city) \\
\hline 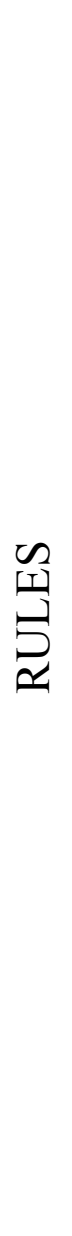 & $\begin{array}{l}\text {-...they restricted us to not download } \\
\text { movies or listening to music online. } \\
\text { Well it's good for the institution, but for } \\
\text { us, it's not because sometimes when } \\
\text { studying we need to take a break and lis- } \\
\text { ten to music or watch something to re- } \\
\text { fresh Ki14 } \\
\text { - ..there are rules which one has to agree } \\
\text { to when logging in to the university net- } \\
\text { works and these rules govern what you } \\
\text { can do here. The rules state that you } \\
\text { can't do things like visit porn sites, } \\
\text { downloading movies and other stuff. } \\
\text { Pi15 } \\
\text { - We are allowed to use our devices in } \\
\text { class as long they don't disturb lectures, } \\
\text { Mi3 } \\
\text { - ... we are only allowed to do things that } \\
\text { are regarded as part of school work and } \\
\text { doing things like watching movies } \\
\text { online is forbidden. SI9 } \\
\text { - I think the Wi-Fi needs to be improved; } \\
\text { the software needs to be updated to the } \\
\text { current versions. Also, they should al- } \\
\text { low us to use some services like torrents. } \\
\text { We should be allowed to enter the labs } \\
\text { with our own laptops as currently, they } \\
\text { won't allow us because they don't want } \\
\text { people stealing the laptops in the labs }\end{array}$ & $\begin{array}{l}\text { - No there are no rules, and that is be- } \\
\text { cause they have no much knowledge } \\
\text { about the internet and the only thing } \\
\text { that they would say is that I am old } \\
\text { enough to know not to do something } \\
\text { that would be offensive to other peo- } \\
\text { ple or too private. Also that you can } \\
\text { stay on the phone while you have } \\
\text { something you should be doing or } \\
\text { you can't be on the phone while eat- } \\
\text { ing, so the rules are such things only. } \\
\text { - Yes, I think there are rules [home] } \\
\text { because you can't really do those } \\
\text { things, you have to ask permission to } \\
\text { use the internet for academic pur- } \\
\text { poses only, and maybe you can use } \\
\text { them when they are not around do } \\
\text { your other stuff but you can't access } \\
\text { the internet for anything other than } \\
\text { academic. Mi3 } \\
\text { - It depends because we are not al- } \\
\text { lowed to be on our phone while din- } \\
\text { ing as a family or during the sleeping } \\
\text { time but our parents don't really have } \\
\text { much control on that, so there are no } \\
\text { rules I can say. Ti3 } \\
\text {-...not rules but WhatsApp is always } \\
\text { an issue with parents when you al- } \\
\text { ways on it but then when they refuse } \\
\text { me WhatsApp I can always go out } \\
\text { and be with my friends and do my } \\
\text { WhatsApp, as long as I have done all } \\
\text { my duties and back in the house at the } \\
\text { right time. Ai1 }\end{array}$ \\
\hline & $\begin{array}{l}\text { - } \\
\text { - } \\
\text { Nocess to bad sites is blocked } \\
\text { series } \\
\text { - } \quad \text { allowed to use own devices }\end{array}$ & $\begin{array}{l}\text { - No parental rules about inter- } \\
\text { net use } \\
\text { - No excessive use mobile and } \\
\text { use during diner }\end{array}$ \\
\hline
\end{tabular}


Rules: The results show that home rules do not affect online activity. As one participant advised, 'No, there are no rules, and that is because they have no much knowledge about the internet and the only thing that they would say is that I am old enough to know not to do something that would be offensive to other people or too private. Also that you cannot stay on the phone while you have something you should be doing or you can't be on the phone while eating, so the rules are such things only' These extrinsic rules are in contrast with intrinsic rules in the university system, e.g. not using cellphones during class time, that regulate access to content.

Table 3. The influence of the home and university community on students' digital access

\begin{tabular}{|c|c|c|}
\hline & UNIVERSITY & HOME (rural \& city) \\
\hline & $\begin{array}{l}\text { - No, I don't have friends who know bet- } \\
\text { ter than me in using the internet.... Yes, } \\
\text { they [Lecturers] do give me enough in- } \\
\text { formation I need because most of the } \\
\text { things I know is because of them. } \\
\text { - I leaned here a lot from my friends; I } \\
\text { didn't learn anything from ICT and lec- } \\
\text { turers because even though there is a } \\
\text { computer lab in my department, we } \\
\text { were told to do books when we want to } \\
\text { access it. Ail } \\
\text { - Yes, I had two friends one doing a } \\
\text { B.Comm General and the other Eco- } \\
\text { nomics we used to do CLT practical to- } \\
\text { gether, and since I was struggling with } \\
\text { computers a lot, they helped me a lot. } \\
\text { Ki14 } \\
\text {-.... but I have friends who still post } \\
\text { their nude pictures online or share de- } \\
\text { rogatory statement online which are } \\
\text { things that may cost them in the future } \\
\text { because I heard employers look at your } \\
\text { online activities. I think they need to be } \\
\text { taught more about avoiding things like } \\
\text { that. Pi15 } \\
\text { Yes, I remember very well the lecturer } \\
\text { was by Dr N. She spoke an about cyber } \\
\text { ers. She also spoke about restricting the } \\
\text { amount of information you give out } \\
\text { online and on social media to avoid } \\
\text { cyber bullies. }\end{array}$ & $\begin{array}{l}\text { - Specifically using the internet, I was never } \\
\text { taught at home, using Microsoft I was } \\
\text { taught that at a community centre but un- } \\
\text { fortunately they didn't have internet, they } \\
\text { were just teaching basic Microsoft word } \\
\text { and excel. Accessing internet there was no } \\
\text { one to teach, you would go to the internet } \\
\text { café and get someone to assist you by con- } \\
\text { nection, how you do it is your struggle, no } \\
\text { one teaches you. Mi2 } \\
\text { - In rural areas one thing is that people who } \\
\text { have already acquired skills that they would } \\
\text { be able to teach those who don't have move } \\
\text { out of the village to better city and we are } \\
\text { left alone to hustle the skills on our own, } \\
\text { when they come back we have already got } \\
\text { the skills on our own and some of them be- } \\
\text { come very interested to assist there and } \\
\text { there in improving what we already have. } \\
\text { Mi2 }\end{array}$ \\
\hline & $\begin{array}{ll}\text { - } & \text { Educators; } \\
\text { - } & \text { Friends/fellow students }\end{array}$ & $\begin{array}{l}\text { - } \quad \text { Parents; Siblings; friends; } \\
\text { - } \quad \text { Internet cafes; libraries }\end{array}$ \\
\hline
\end{tabular}


Community: The same disparities were found in the community's role players, which also differ in ICT capacity and scale of influence. Unlike the university, which had an ICT help desk, lecturers and peers the home had inadequate funding from parents and little technical help from internet cafes. Participant Mi2 'Specifically using the internet I was never taught at home, using Microsoft I was taught that at a community centre but unfortunately they didn't have internet, they were just teaching basic Microsoft Word and Excel. Accessing internet there was no one to teach, you would go to the internet café and get someone to assist you by connection, how you do it is your struggle, no one teaches you.'

Table 4. The effect of division of labour on students' digital access

\begin{tabular}{|c|c|c|}
\hline & UNIVERSITY & HOME (rural \& city) \\
\hline 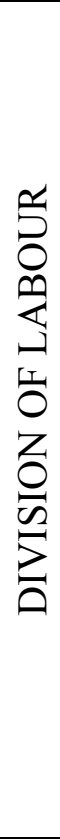 & $\begin{array}{l}\text { - They [ICT support] give me support } \\
\text { like ICT when I have a problem with } \\
\text { my laptop I do go to them, and they fix } \\
\text { it for me so that I can be able to use it } \\
\text { and also access the internet. Ni6 } \\
\text { - [ICT support] they do not assist us } \\
\text { with the learning, but they help with } \\
\text { setting up our login profiles, our } \\
\text { emails and printing our student cards. } \\
\text { Si9 } \\
\text { - Lecturers also do support as they give } \\
\text { us support on how to access infor- } \\
\text { mation especially about certain pro- } \\
\text { jects that they give us." } \\
\text { "The tutors move around helping the } \\
\text { struggling students but often we are } \\
\text { taught as a group and some people } \\
\text { can't understand things quickly and } \\
\text { the class may even end and they still } \\
\text { do not understand what we were learn- } \\
\text { ing" Si9 }\end{array}$ & $\begin{array}{l}\text { - "[Siblings] my sister who is } 5 \text { years } \\
\text { older than me taught me most of the } \\
\text { things about technology, how to use a } \\
\text { phone and most of the things I know } \\
\text { now I learned from her." Si8 } \\
\text { - "[Friend] I can't say I learned some- } \\
\text { thing (from friends) because the com- } \\
\text { munity I come from is a bit behind, in } \\
\text { fact, I had to be the one teaching them } \\
\text { when I went home"Si15 } \\
\text { " "[Neighbours] I had a neighbour who } \\
\text { was studying engineering at Ibika. He } \\
\text { was advanced in technology so I used } \\
\text { to follow him. He owned a computer } \\
\text { and a smart phone and I was always } \\
\text { with him. However, I was young then } \\
\text { and all I knew about technology was } \\
\text { watching movies on his laptop. He was } \\
\text { the person who motivated me to get an } \\
\text { interest in the computer world." Silo } \\
\text { " "[Parents] at my home there is no one } \\
\text { to help me with the money to buy bun- } \\
\text { dles because no one has it." Oi6 }\end{array}$ \\
\hline & $\begin{array}{l}\text { - Technical support from } \\
\text { ICT Help desk; } \\
\text { - Academic content from } \\
\text { Lecturers; } \\
\text { - Practical Assistance from } \\
\text { Fellow students }\end{array}$ & $\begin{array}{l}\text { - } \quad \text { Parents provide funding; } \\
\text { - } \quad \text { Siblings \& friends assist; } \\
\text { - Internet cafes \& libraries } \\
\text { provide Access }\end{array}$ \\
\hline
\end{tabular}

Division of labour: There is also a sharp contrast between the divisions of labour, which was found to be less diverse and less effective in the home activity system. For instance, very few participants had any influence from friends, neighbours and libraries when they are at home. Participant Si10 was exceptional 'I had a neighbour who was 
studying engineering at Ibika. He was advanced in technology, so I used to follow him. He owned a computer and a smart phone, and I was always with him. However, I was young then, and all I knew about technology was watching movies on his laptop. He was the person who motivated me to get an interest in the computer world.' Other participants only reported lack of actors who should otherwise play role that support ICT access. This is due to lack of capacity on the part of these actors involved in the home activity system.

Table 5. How digital tools are being used by students at home and university activity systems

\begin{tabular}{|c|c|c|}
\hline & UNIVERSITY & HOME (rural \& city) \\
\hline$\stackrel{0}{0}$ & $\begin{array}{l}\text { - ".. here at school I have free Wi-Fi } \\
\text { all the time. ... So on a daily basis, } \\
\text { I would say I get about 9-10 hours } \\
\text { of internet access." Si8 } \\
\text { ".... almost } 90 \% \text { of my classmates } \\
\text { have laptops, and } 99,5 \% \text { have } \\
\text { smartphones." Ai1 }\end{array}$ & $\begin{array}{l}\text { - At home [access] is a struggle with } \\
\text { expensive data as you know... I } \\
\text { can't even use my laptop because to } \\
\text { connect it to internet is very expen- } \\
\text { sive at home, so I use my phone' } \\
\text { Ail } \\
\text { "Flexibility is serious caution and } \\
\text { the fact that you can't compare } \\
\text { desktop with the phone then you } \\
\text { can't really be flexible on the phone } \\
\text { as you would do on a desktop." Mi2 } \\
\text { "we have limited resources when it } \\
\text { comes to technology in the Eastern } \\
\text { Cape, and the teachers seem not to } \\
\text { take technology serious, and they } \\
\text { do not dedicate time to teach stu- } \\
\text { dents how to use computers. There } \\
\text { is also a lack of internet connectiv- } \\
\text { ity. I started to hear about Wi-Fi } \\
\text { when I got to university."Ki14 }\end{array}$ \\
\hline & $\begin{array}{ll}\text { - } & \text { Computers; } \\
\text { - } & \text { Smart phones; } \\
\text { - } & \text { Free Wi-Fi } \\
\end{array}$ & $\begin{array}{l}\text { - } \quad \text { Smart phones; } \\
\text { - } \quad \text { Data Bundles; }\end{array}$ \\
\hline
\end{tabular}

Tools: These ICT tools on the university system are more in variety and effectiveness that those at home. A key difference is lack of WIFI which restricts access to the home system as participant Ail puts it, 'At home [access] is a struggle with expensive data as you know... I can't even use my laptop because to connect it to internet is very expensive at home, so I use my phone.' 


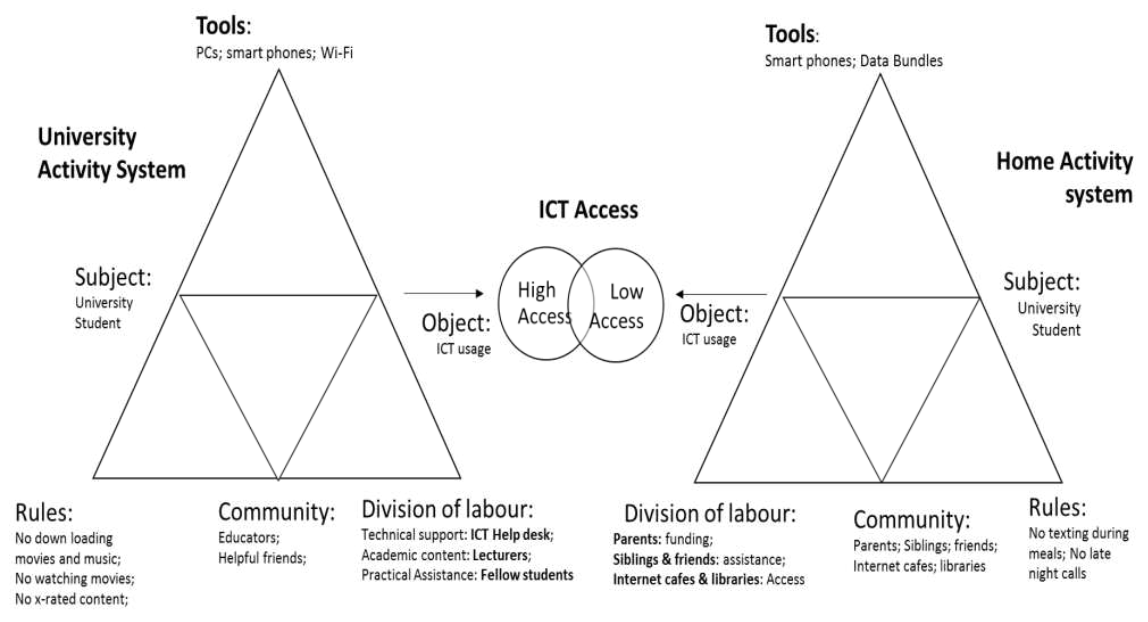

Fig. 2. Interaction between the university and home activity system

Based on the interview results presented in tables 1 to 5 , figure 2 shows how the components of third generation activity theory reveal the differences in ICT access, capacity and scope between the home and the university systems. See figure 2. For the graphical representation of the activity systems.

\section{Discussion}

This paper has attempted to promote inclusive ICT assess by investigating the disparities between access at the home and institutional levels and discussing how to address them. It used university students operationalized as subjects for assessing the two activity systems as articulated by Engeström's [1] third generation activity theory. The university (operationalized as activity system 1) was presented as a proxy of institutions that provides access to its patrons. It was selected because educational institutions provide about $11.3 \%$ of Internet access in the Eastern Cape. The home activity system (operationalized as activity system 2) represents students' rural and city homes where they reside during the holidays and after they complete their studies. The internet access in the home activity system was found to be mainly through mobile data bundles. Mobile access amounts to $80 \%$ of internet access in the Eastern Cape of South Africa [39]. This does not suggest that the entire $80 \%$ of mobile access in the province is used on the home activity system, the researchers observed that a majority of institutional internet users in the Eastern Cape also use mobile access.

Our findings show that Internet access is limited on the home front yet it is unlimited at the institutional activity system. The informants claim that their internet access drops from $100 \%$ at university to about $30 \%$ when they go home. Participant Si8 advised, '.. here at school I have free Wi-Fi all the time. ... So on a daily basis, I would say I get 
about 9-10 hours of internet access.' This disparity is expected to also occur between the home and other institutional fronts like the workplace. This is mainly because of the access costs, which discourage many domestic users from subscribing to conventional broadband access. As participant Ail advised, 'At home [access] is a struggle with expensive data as you know... I can't even use my laptop because to connect it to internet is very expensive at home, so I use my phone.' The home activity system also lacks ICT devices that are necessary for connecting to the internet. ICT devices are operationalized in this study as tools that mediate between subject and object to produce the outcome of ICT enable opportunities. Very few rural and high-density suburb inhabitants have personal computers and smartphones.

While this may be due to lack of awareness of the need for Internet access, we found that it is also due to lack of financial resources. There is a need to address the socioeconomic inequalities and socio-political issues that cause these disparities. Both lack awareness, and low income are linked to the socio-historical contours of the social exclusionary policies of the apartheid Era as articulated by Kruger et al., [44].

The study found some regulatory and ethical rules that govern the usage of ICTs at university yet on the home activity system these rules were rather insignificant. This is arguably because of the need to address the misconduct that accompanies high usage at the university while the insignificant online activity at home hardly warrants the intervention of parents and guardians. As interviewee Ki14 put it, '..at home, there are no rules they don't mind if I'm using my laptop.' We found that part of their lack of involvement emanates from their lack of digital skills.

The exclusion from the digital economy is so widespread that the participants reported that in their home communities, the students have very little to no contact with anyone who can help them to develop digital skills. As stated by one participant, '... [in] my home town Bizana most people know nothing about using mobile devices or the internet.' This suggests that the young people that are not enrolled in universities or employed by any institution have limited contact and scope to develop the digital skills that are necessary for exploiting ICT enabled opportunities that are getting more important in the information age.

There is also a difference in the division of labour. The university system has technical skill and assistance from lecturers, fellow students and ICT helpdesk knowledge support, yet the home can only provide limited financial assistance and almost no digital skills at all. Participant Si15 said, 'I can't say I learned something (from friends) because the community I come from is a bit behind, in fact, I had to be the one teaching them when I went home.' Participant Oi6 added '[Parents] at my home there is no one to help me with the money to buy bundles because no one has it.' Another participant suggested that poor support is due to lack of knowledge of the usefulness of the internet. In her own words, '... [in] my home town Bizana most people know nothing about using mobile devices or the internet. As a result, even when I asked for money to go to the library they would not understand why I need to go to the library.' This is a serious disadvantage for young people growing up in the digital era where more and more government and business to citizens' information is migrating to online platforms.

Since activity theory assists use to unearth the contradictions in the phenomena under investigation [45], we found different levels of access between activity systems that enjoy the same coverage yet there are no rules or actors that inhibit use of ICTs by the marginalized people. The home and institutional activity systems have roughly the 
same 3G, 4G and LTE mobile coverage in the Eastern Cape. The same applies to fixed internet infrastructure within city limits yet the home activity system has less access. As a result, the disparities in access and usage cannot be conceptualized as a spatially determined anomaly but rather as socio-economic and socio-culturally defined one. For that reason, the ICT infrastructure and mobile operator companies may claim to be serving the nation equally yet the end users face different levels of access. There is, however, a discernible co-existence of being previously disadvantaged and being currently uninvolved in the digital world as typified by the home activity system. According to Hickey and du Toit, [46] social exclusion can be associated with political, economic, socio-cultural and spatial imperative and these are said to be closely related to long-term historical processes. Such a situation represents adverse incorporation on the part of the users on the home front [46].

\section{$6 \quad$ Limitations and conclusion}

This study made its contribution to inclusive access by identifying the factors that shape the access disparities between the home and institution activity systems. While it has revealed the of glaring disparities in access between the two activity systems, the paper faces limitations in attempting to assess the socio-historically determined factors and effects of exclusion thorough the eyes of students since they did not experience the causal influence of apartheid. We conclude that there is evidence of socio-demographically shaped patterns of social exclusion within the Eastern Cape Province. While we found no deliberate effort to perpetuate exclusion by social status, this study shows that it is inadequate to ensure uniform investment in ICT infrastructure between the home and the institution. There is a desperate to address the socio-political and socio-economic factors before equal opportunities in the digital front can be realized. We confirm that ICT access disparities require no technological deterministic solution. Future research must consider the using adverse incorporation theory for assessing access inequalities because it enables an assessment of the effect of localized livelihood strategies over both time and space.

\section{$7 \quad$ Acknowledgement}

This research project was jointly funded by the South African Medical Research Council (SAMRC) and Forte, the Swedish Research Council for Welfare, Working Life and Welfare.

\section{References}

1. Engeström, Y. Expansive learning at work: toward an activity-theoretical reconceptualization, Journal of Education and Work, 14 (1) pp. 133-56. (2001).

2. Walsham, G. Are we making a better world with ICTs? Reflections on a future agenda for the IS field. Journal of Information Technology, 27(2), 87-93. (2012). 
3. Qureshi, S. Are we making a Better World with Information and Communication Technology for Development (ICT4D) Research? Findings from the Field and Theory Building, Information Technology for Development, 21:4, 511-522, (2015)

4. Sahay, S. Are we Building a Better World with ICTs? Empirically Examining this Question in the Domain of Public Health in India, Information Technology for Development, 22:1, 168-176, (2016).

5. Khaliq IH, Naeem B, Abbas Q, Khalid S. Contribution of ICT to Poverty Reduction among Women in Kilosa District. J Bus Fin Aff 6:(1) 238(2016)

6. Takavarasha Jr, S., Adams, C., \& Cilliers, L. Community networks for addressing affordability of ICT access in African rural areas: A case study of Zenzeleni, Makhosi, South Africa. In Eds S. Takavarasha Jr \& C. Adams, Affordability Issues Surrounding the Use of ICT for Development and Poverty Reduction. IGI Global, Hershey PA., USA (2018).

7. Van Zyl, O., Alexander, T., De Graaf, L. \& Mukherjee, K. ICT for Agriculture in Africa. In (Eds) E. Yonazi, T. Kelly, N. Halewood and C. Blackman. E-Transform Africa: The transformational use of ICT in Africa. (2012)

8. Al-Zahrani, A. Toward Digital Citizenship: Examining Factors Affecting Participation and Involvement in the InternetSociety among Higher Education. International Education Studies; 8(12) pp 203-217(2015)

9. de Haan A and S. Maxwell. Editorial: Poverty and Social Exclusion in North and South, IDS Bulletin,29(1): 1-9.(1998).

10. Cilliers, L \& Samarthya-Howard, A. Everyone will be connected': Free Basics in Africa to support ICT4D. In Eds S. Takavarasha Jr \& C. Adams, Affordability Issues Surrounding the Use of ICT for Development and Poverty Reduction. IGI Global, Hershey PA., USA(2018).

11. Van Der Vyver, A. G. A Model for Economic Development with Telecentres and the Social Media: Overcoming Affordability Constraints. In Eds S. Takavarasha Jr \& C. Adams, Affordability Issues Surrounding the Use of ICT for Development and Poverty Reduction. IGI Global, Hershey PA., USA. (2018).

12. Zanamwe, N., Rupere, T., Mapako, B., \& Nyambo, B., Fostering Affordability of ICT Access in Developing Countries Through Infrastructure Sharing: The devil is in the detail. In Eds S. Takavarasha Jr \& C. Adams, Affordability Issues Surrounding the Use of ICT for Development and Poverty Reduction. IGI Global, Hershey PA., USA. (2018).

13. Skaletsky, M., Soremekun, O. \& Galliers, R.D., Information Technology for Development (2013): The Changing - and Unchanging - Face of the Digital Divide: an Application of Kohonen Self-Organizing Maps, Information Technology for Development, (2013).

14. Gilwald, A. Beyond access. Addressing digital inequality in Africa. PAPER SERIES: NO. 48 - MARCH 2017. (2017). Retrieved from: https://www.cigionline.org/sites/default/files/documents/GCIG\%20no.48_0.pdf

15. Vengerfeldt, P. Digital divide - questions beyond access. Editor: Roger Silverstone, (eds) EMTEL conference in London, April 23rd-26th, 2003 (2003).

16. Bednar, P. \& Welch, C.(2017) The Innovation-Diffusion Cycle: Time for a Sociotechnical Agenda. Twenty-Fifth European Conference on Information Systems (ECIS), Guimarães,Portugal, 2017

17. United Nations, Information and communications technologies for inclusive social and economic development. Commission on Science and Technology for Development Seventeenth session Geneva, 12-16 May 2014. (2014)

18. Du Toit, A. and Neves, D. (2007a, forthcoming) 'In Search of South Africa's Second Economy: reflections on chronic poverty, vulnerability and adverse incorporation in Mt Frere and Khayelitsha. Paper prepared for the conference on Living on the Margins: Vulnerability, 
social exclusion and the state in the informal economy; Cape Town, 26-28 March 2007. PLAAS and CPRC. (2007).

19. UNESCO. Poverty and Digital Inclusion: Preliminary Findings of Finding a Voice Project. The United Nations Educational Scientific \& Cultural Organization, New Deli, India. (2007)

20. Zavaleta. D., Samuel, K., \& Mills, C. Social Isolation: A conceptual and Measurement Proposal. OPHI WORKING PAPER. NO.67 (2014)

21. MacLachlan, M., Khasnabis, C. \& Mannan, H. Inclusive health. Tropical Medicine and International Health. 17 (1) pp 139-141(2012).

22. Angeli, F. \& Jaiswal, A.K., Business Model Innovation for Inclusive Health Care Delivery at the Bottom of the Pyramid. Organization \& Environment. 29(4) 486-507(2016).

23. Palomino, M., C., P. Future teachers to use ICT for inclusive education. Digital Education Review - 31, June (2017)

24. Sachs, J. The End of Poverty. Penguin Press (2005).

25. Roupa, Z., Roupa, Nikas, M., Gerasimou, E., Zafeiri, V., Giasyrani, L., Kazitori, E., \& Sotiropoulou, P., The use of technology by the elderly. Health Science Journal, 4(2) pp:118126. (2010).

26. Abascal, J., Civit, A, \& Nicolle, C., Universal Accessibility and the Digital Divide. In Editors, Paula Kotzé,

27. Gary Marsden, Gitte Lindgaard, Janet Wesson, Marco Winckler (eds) 14th IFIP TC13 Conference on Human-Computer Interaction, INTERACT 2013 Workshop on Rethinking Universal Accessibility: A broader approach considering the digital gap, 2013. (2013)

28. Avgerou, C. Information systems in developing countries: a critical research review, Journal of Information Technology, 23(3), 133-146. (2008).

29. Avgerou, C. Discourses on ICT and development. Information technologies and international development 6(3),1-18. (2010).

30. Mhlanga, B. Information and communication Technologies (ICTs), Policy for change and the mask for development: A critical analysis of Zimbabwe's E-Readiness Survey Report. IJISDC, 28(1), 1-16(2006).

31. Dusek, V. Philosophy of Technology: An introduction. Oxford: Blackwell (2007).

32. Best, L. M. \& Rajendra, K. Sustainability Failures of Rural Telecenters: Challenges from the Sustainable Access in Rural India (SARI) Project. Information Technologies and International Development. 4. 31-45 (2008).

33. Karanasios, S. Framing ICT4D research using activity theory: A match between the ICT4D field and theory? Information Technologies \& International Development, 10(2), 1-17. (2014).

34. Slavova, M. \& Karanasios, S. When Institutional Logics Meet Information and Communication Technologies: Examining Hybrid Information Practices in Ghanaian Agriculture. Journal of the Association for Information Systems (Forthcoming).

35. Robertson, I. Sustainable e-learning, activity theory and professional Development. In Editors: Roger Atkinson and Clare McBeath, Editors: Hello! Where are you in the landscape of educational technology? (Eds) Proceedings ascilite Melbourne (2008)

36. Bennett, E. Activity theory: what does it offer elearning research? In: Editors, W.B. Yeats (Eds) ALT-C 2009 In Dreams Begins Responsiblity, 8-10 September 2010, Manchester(2010).

37. Karanasios, S. Toward a Unified View of Technology and Activity: The Contribution of Activity Theory to Information Systems Research. Information Technology \& People. (2017).

38. Vygotsky, L. Mind in society: the development of higher psychological processes. Cambridge, Mass: Harvard University Press. (1978). 
39. Mail \& Guardian, (2018). Is South Africa the unequal society in the world? Retrieved from: https://mg.co.za/article/2015-09-30-is-south-africa-the-most-unequal-society-in-theworld

40. My Broadband Retrieved from https://mybroadband.co.za/news/telecoms/127450internet-access-in-south-africa-best-and-worst-provinces.html (2015)

41. Klein, H. \& Myres, D. A set of principles for conducting and evaluating interpretive field studies in information systems. MIS Quarterly 23 (1), pp. 67-94 (1999).

42. Glaser B.G. Basics of Grounded Theory Analysis. MillValley: Sociology Press. (1992)

43. Matavire, R., \& Brown, I. Profiling Grounded theory approaches in information systems research. European Journal of Information Systems, 22(1), 119-129. (2011).

44. Engeström, Y 1987, 'Learning By Expanding: An Activity Theoretical Approach to Developmental Research', Orienta-Konsultit, Helsinki. (1987).

45. Kruger, S., du Toit, A., Ponte, S. De-racialising exploitation: 'black economic empowerment' in the South African Wine sector. DIIS working Paper no 2006/34. Copenhagen: Danish Institute for International Studies.(2006).

46. Engestro"m, Y. \& Sannino, A. Discursive manifestations of contradictions in organizational change efforts A methodological frameworkJournal of Organizational Change Management 24 (3), pp. 368-387(2011).

47. Hickey, S. \& du Toit, A. Adverse incorporation, social exclusion and chronic poverty. CPRC Working paper 81. (2007). Retrieved from: http://www.chronicpoverty.org/uploads/publication_files/WP81_Hickey_duToit.pdf

48. Du Toit, A. Forgotten by the Highway: Globalization and Chronic Poverty in Ceres,

49. South Africa. Bellville: PLAAS Research paper (2004). 